\title{
Geology of the Eastern Part of the Volcanic-Kendeng Zone of East Java: Stratigraphy, Structures and Sedimentation Review from Besuki and Situbondo Areas
}

\section{Geologi Bagian Timur Zona Volkanik Kendeng Jawa Timur: Kajian Mengenai Stratigrafi, Sedimentasi dan Geologi Struktur di daerah Besuki dan Situbondo}

\author{
Agus Handoyo Harsolumakso, Dardji Noeradi, Alfend Rudyawan, Dadan Amiarsa, Satryo Wicaksono \\ and Affan A. Nurfarhan \\ Geology Program, Faculty of Earth Sciences and Technology, Institut Teknologi Bandung \\ Jalan Ganesa 10 Bandung, 40132, Indonesia \\ email: agush@gl.itb.ac.id \\ Naskah diterima : 16 Mei 2019, Revisi terakhir : 07 Juli 2019 Disetujui : 07 Juli 2019, Online : 08 Juli 2019 \\ DOI: http://dx.doi.org/10.33332/jgsm.v20i3.465
}

\begin{abstract}
The Tertiary stratigraphy of Situbondo was constructed by a series of volcanoclastic-carbonate turbidite facies of Menuran Formation with Pacalan limestone Member, and Leprak Formation. These formations formed a regional east-west trending circular anticlinorium. The Tertiary formations were covered by Quaternary volcano-clastic Ringgit Formation and subsequent younger Bagor volcanic products. The oldest Tertiary rock units are the Late Miocene-Pliocene Menuran Formation, with Pacalan Limestone Member. Formation is mainly composed of foram-rich marls and calcareous, sometimes tuffaceous sandstones, with conglomerate intercalations. Sedimentation of this formation is interpreted as to be a mixing, from proximal to distal turbidite, involving volcaniclastic and carbonate sources, in a bathyal open marine environment. The Early Pliocene Leprak Formation overlies conformably the Menuran Formation, which consists of alternating calcareous sandstones and tuff sandstones deposited in a bathyal open marine environment with proximal turbidite mechanism suggesting that basin depocenter was located to the east. Up to Late Pliocene, the region was dominated by developments proximal turbidite volcanoclastic sedimentation of The Leprak Formation, contemporaneous with increasing volcanic activity in the south. Deformation of Plio-Pleistocene in Java is believed to be the last major tectonic period, which forms the westeast trending structures. In Situbondo area, folding structures in this direction involves the Neogene Menuran Formation, Pacalan Member and Leprak Formation. Volcanic activity persists, and increases, with the activity of Ringgit-Beser volcano in Pleistocene. These late events of magmatism, volcanism and uplift were contributed to the last structural configuration of the area.
\end{abstract}

Keyword : Situbondo, structural geology, volcanic-kendeng zone, stratigraphy
Abstrak- Stratigrafi Tersier Situbondo dibangun oleh serangkaian fasies vulkanoklastik-karbonat turbidit Formasi Menuran dengan Anggota Batugamping Pacalan, dan Formasi Leprak. Formasi ini membentuk antiklinorium yang melingkar berarah barat-timur. Formasi Tersier ini ditutupi oleh batuan gunung berapi klastik Kuarter dari Formasi Ringgit dan produk vulkanik Bagor yang lebih muda berikutnya. Unit batuan Tersier tertua adalah Formasi Menuran yang berumur MiosenPliosen Akhir, dengan Anggota Batugamping Pacalan. Formasi ini terutama terdiri dari napal yang kaya akan foraminifera, dan batupasir gampingan, tufa, dengan interkalasi konglomerat. Sedimentasi dari formasi ini ditafsirkan sebagai pencampuran dari sistem turbidit proksimal ke distal yang melibatkan sumber-sumber volkaniklastik dan karbonat pada zona bathyal lingkungan laut terbuka. Formasi Leprak yang berumur Pliosen Awal menumpang selaras diatas Formasi Menuran. Formasi ini terdiri dari batupasir berkapur dengan perselingan batupasir tufaan yang diendapkan pada zona bathyal di lingkungan laut terbuka dengan mekanisme turbidit proksimal yang menunjukkan deposenter cekungan terletak di timur. Hingga Pliosen Akhir, wilayah ini didominasi oleh perkembangan sedimentasi proksimal turbidit volkanoklastik Formasi Leprak, bersamaan dengan aktivitas vulkanik di selatan. Deformasi Plio-Pleistosen di Pulau Jawa umumnya diyakini sebagai periode tektonik besar terakhir, yang membentuk struktur berarah barat-timur. Di daerah Situbondo, struktur perlipatan ini melibatkan batuan Neogen Formasi Menuran, Anggota Pacalan dan Formasi Leprak. Aktivitas vulkanik berlanjut, dan meningkat, dengan aktivitas gunung berapi Ringgit-Beser di pada umur Pleistosen. Interaksi antara aktivitas gunungapi dan deformasi regional ini memberikan kontribusi terhadap pembentukan konfigurasi struktural terakhir dari daerah ini.

Keyword : Situbondo, geologi struktur, zona gunungapiKendeng, stratigrafi 


\section{INTRODUCTION}

A group of Tertiary sedimentary rocks outcrop formed an elongated anticlinorium windows within a volcanic complex of Ringgit Beser, Situbondo area has been overlooked by previous researcher from the time Dutch geologists summarised by van Bemmelen (1949) and Marks (1957) until Indonesia Geological Agency (GRDC) remapping campaigns (Pendowo, 1991; Agustyanto and Santosa, 1993) on a scale of 1: 100,000 have been done with stratigraphic nomenclature refers to the previous authors. This paper aims to propose a detailed stratigraphy using biostratigraphy, facies, and structural style of the area to develop regional synthesis of the geology of Besuki and Situbondo areas and evaluation of petroleum systems to support hydrocarbon exploration in the area.

Detailed geological mapping and stratigraphic measurements have been carried out in the area of around District Mlandingan, Besuki, District Klabang Bondowoso and around Situbondo (Figure 1). The study area covers an area Situbondo in the north and a small regency in the south. Northern region is the coastal plain bordering the Madura Strait. The main town is traversed by the road across Besuki District in the north in the direction of Situbondo. In the south, the City Bondowoso connected to both cities via the district road.

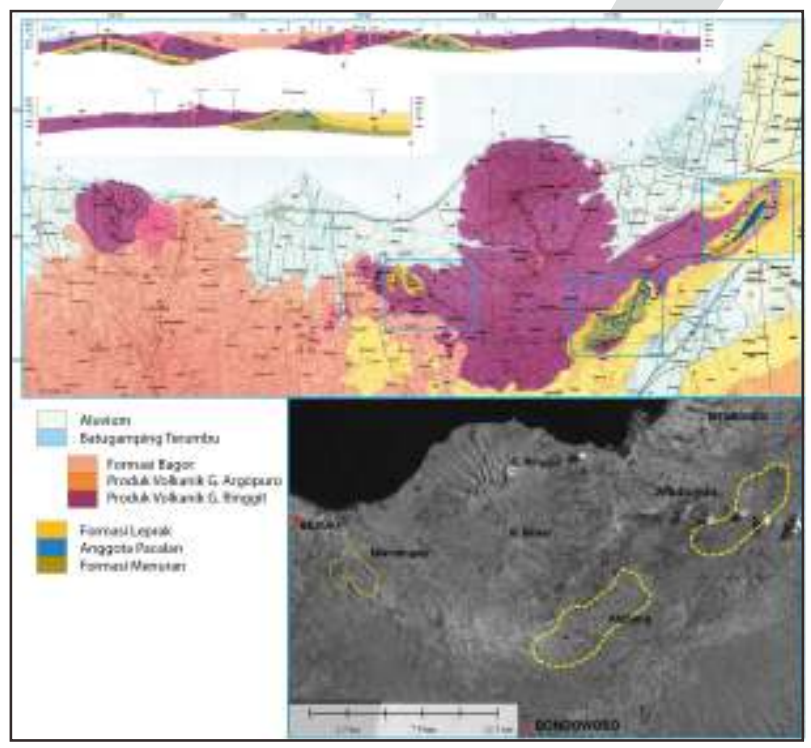

Source:Pendowo, 1991 and Agustyanto \& Santosa, 1993

Figure 1. Location of the investigation included 3 regional mapping (in blue rectangle) with detailed stratigraphic measurements. The background is the Regional Geological Map Sheet Besuki and Situbondo.

\section{PHYSIOGRAPHY AND TECTONIC SETTING}

The Rembang Anticlinorium covers eastern spurs part of Java and Madura Island (van Bemmelen, 1949) to the north of the eastward plunging Kendeng Anticlinorium under the Brantas River Delta (Figure 2). Narrow strip of the north coast of the eastern spurs of Java showing folded Plio-Pleistocene sediments, which covered by several small volcanos.

The study area is located in the southern part of East Java Back Arc Basin, which borders with Java Volcanic Arc in the south, Southern High to the north and Southern Basin to the south associated with strike-slip fault zone (Rembang-Madura- Kangean) (Figure 3). Structure in the south in general has a west-east direction as the general pattern of Java at the end of the Plio-Pleistocene tectonics resulted from the continuous subduction between the Indo-Australian plate underneath Sundaland (Hall, 2012). This feature is not visible because virtually all areas occupied by Quaternary Volcano and its product, except for one point anticlinorium between Besuki and Situbondo, south of the Mount Ringgit-Beser. This anticlinorium structure with east-west direction form a circular, the incidence may be related to volcanic activity after the deformation of the Plio-Pleistocene folding. The west facing detailed geomorphology diagram drawn by van Bemmelen (1938; Figure 2) showing the relationship between the anticlinorium and the younger volcanic complex.

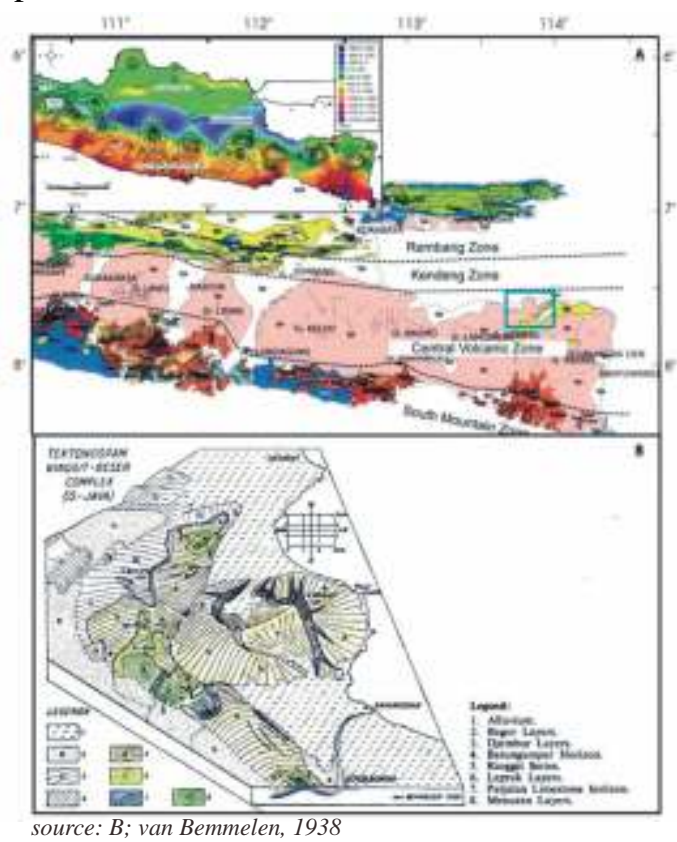

Figure 2. Physiographic Map of eastern Java (A; redrawn from van Bemmelen, 1949) inset on the top left corner showing the modern zone generalization using gravity data from Smyth et al. (2008) and block diagram sketch the of Ringgit-Beser Complex showing the morphology of volcanoes and folding structure with exposed rocks and Tertiary volcanic products from various sources. 


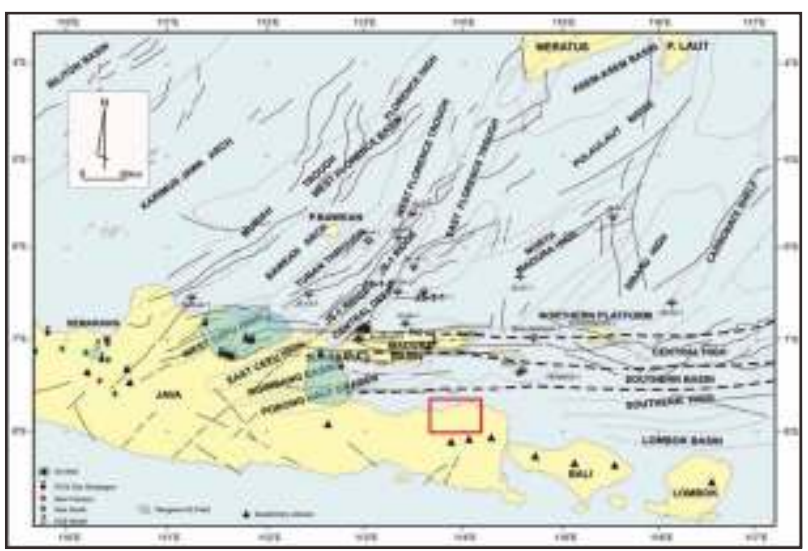

Source: Sribudiyani et al., 2003, Sapiie et al., 2006

Figure 3. Elements of the East Java Basin regional tectonics and hydrocarbon occurrences information. The research area is shown in blocks.

\section{STRATIGRAPHY}

Regional stratigraphy partly refers to the Rembang Zone in the north while the south should be a part of Kendeng zone and towards the south is part of the Volcanic Java today (see Figures 2 and 3). Subsurface data from well (KKE-1, ridge-1, MW-1, Q-1, MDA-3 and Baluran-1) generally refers to the Rembang Zone while only a few of data obtained in the southern part that referred to the Kendeng Zone. Therefore, stratigraphic relationship used is from subsurface data and from the island of Madura (Mulhadiono et al., 1984), showing similar stratigraphy (Figure 4).

Surface geology data obtained from the BesukiSitubondo and surrounding areas suggests that the oldest rock units is the Late Miocene-Pliocene Menuran Formation which consist of alternating calcareous sandstone and marl with limestone known as Pacalan Member. This unit may correlate to the Paciran Formation which is conformably on top of the Pasean Formation, consisting of massive limestone and reef limestone containing algae, coral and large foraminifers. The Pamekasan Formation in Madura island, which consist of sandy clay containing shells of molluscs, can be correlated with the Formation Leprak in Besuki-Situbondo areas with different facies containing more volcanic fragments.

Fluvial plains mainly occupy the area around the main flow Besuki Deliwang River which flows into the Cape Ketah and around Situbondo with the main stream Sampeyan River, flows into the Panarukan Valley. This plain is a further development sediment accumulation from denudation of the volcanic hills and the folded Tertiary sediments since the Late Pleistocene. Coastal sediment occupying most of the plains and volcanic hills of the bay from Mount Ringgit-Beser.
Circular ridge composed of mainly Neogene rocks exposed at the foot of Mount Ringgit-Beser following the general direction of the folds. Other fairly steep and irregular hills generally occupied by the Quaternary and volcanic products. Some revisions to the stratigraphy from the older manuscripts (e.g. Pendowo, 1991; Agustyanto and Santosa, 1993) are presented in Figure 5.

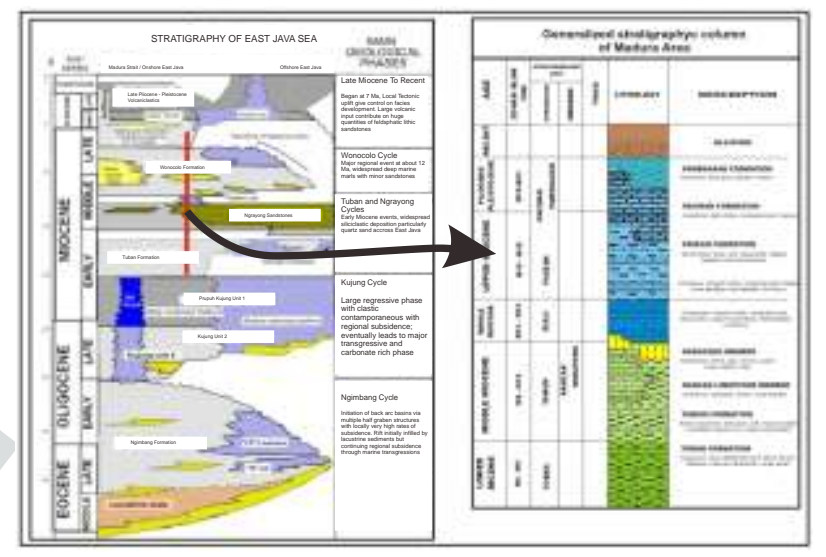

Source:Mulhadiono et al., (1984)

Figure 4. Stratigraphy of the North East Java (Mudjiono and Pireno, 2001) and the island of Madura.

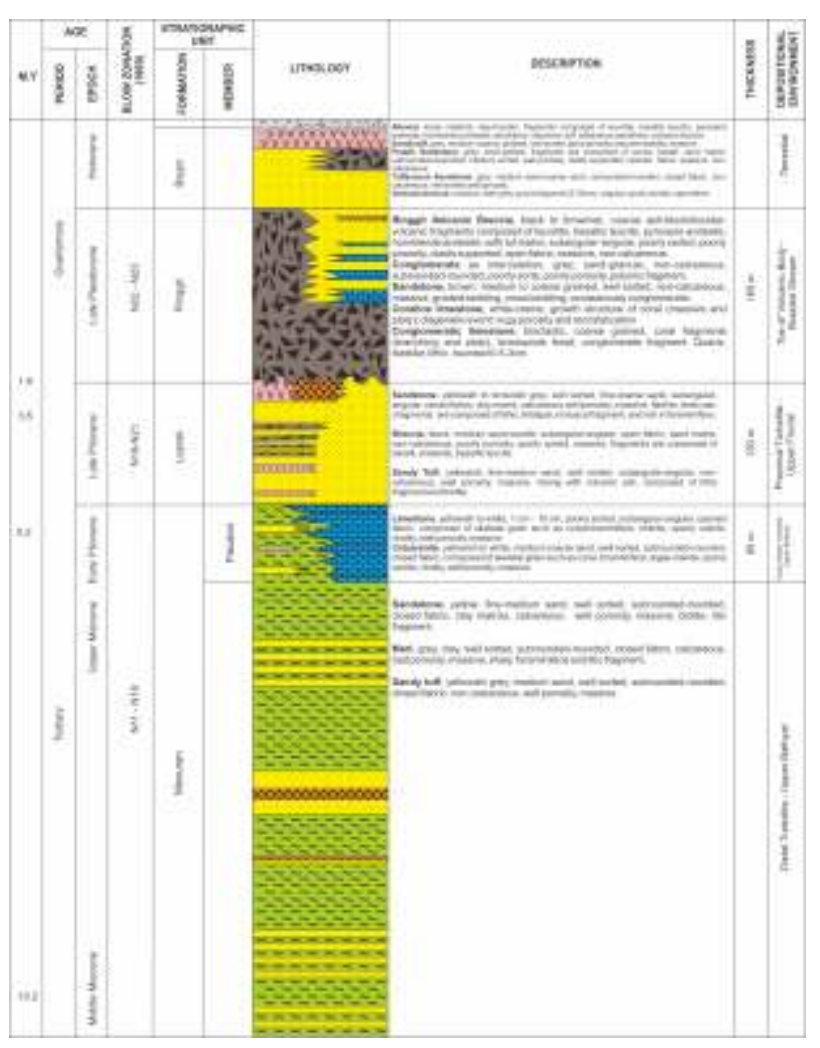

Figure 5. Stratigraphy of Situbondo and surrounding areas. 


\section{Menuran Formation}

Menuran Formation exposed in three areas of mapping, Mlandingan, Klabang and Situbondo with no different lithologic changes. Formation is mainly composed of marl and calcareous sandstones with intercalations of tuff. Generally marl is light brown rich in foraminifers. Calcareous sandstone, fine to medium-sized, alternating with marl with variations in thickness ranges between $10-50 \mathrm{~cm}$ (Figure 6). In some places the thickness reaches more than $80 \mathrm{~cm}$. Parallel and wavy laminations are commonly observed in the sandstone sequences. Conglomerates intercalations are found in the Kali Bluncong, Klabang, with common graded bedding structure on coarse sandstone sequence.

The sandstone is generally lithic-arkose with the main components of rock fragments (lithic) and plagioclase and small amount of mafic minerals pyroxene, hornblende and biotite. Bioclast fragments commonly encountered. Matrix is dominated by clay minerals cemented in partly carbonate and iron oxide cements. The tuff is mainly vitric tuff with dominant volcanic glasses, crystals consist of plagioclase, pyroxene, hornblende and opaque minerals. Some glasses were altered into clay minerals.

The formation is inferred to have age ranges from N16N19, Late Miocene-Early Pliocene. Zircon radiometric dating contained in the tuff sequence (Pedowo, 1991) concluded that the age of $7.26 \pm 1.13 \mathrm{Ma}$ or Late Miocene. The relatively abundant of benthic foraminifera is generally indicated an open marine environment in the upper bathyal zone (Table 1).

The presence of Globocassidulina and other transported fauna including reworked larger forams indicating a possible mechanism turbidite environment. Some examples show middle neritic fauna in a small number such as, Lenticulina tangens, Ammonia, Heterolepa praecinctus and Eponides repandus. Thus concluded that the Menuran Formation was deposited in an open marine environment in the upper bathyal zone via a turbidite mechanism.

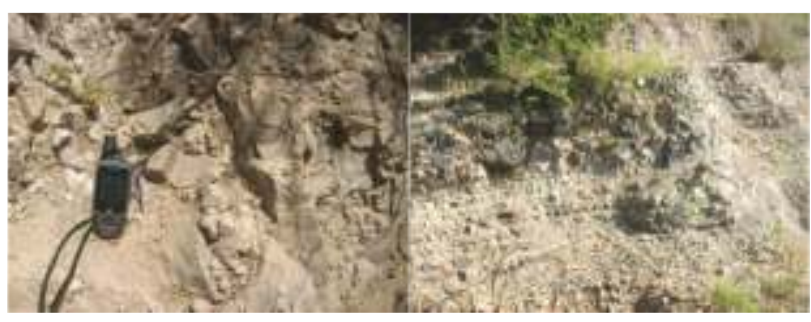

Figure 6. Outcrops of marl (left) and alternating sandstone and marl of the Menuran Formation (location ST-3, Situbondo)
Table 1. Results of foraminifera determination showing the presence of planktonic foraminifera indicative with the following age ranges

\begin{tabular}{|c|c|c|c|}
\hline Species & Interpreted ages & Species & $\begin{array}{c}\text { Interpreted Depositional } \\
\text { Environment }\end{array}$ \\
\hline $\begin{array}{l}\text { Sphaeroidinella dehiscens } \\
\text { Sphaeroidinella dehiscens immature } \\
\text { Sphaeroidinellopsis seminulina. } \\
\text { Globigerina venezuelana } \\
\text { Globigerina bulloides } \\
\text { Neooglobouadrina acostaensis } \\
\text { Globorotalia tumida }\end{array}$ & $\begin{array}{c}\text { Late Miocene (N19 } \\
\text { Late Miocene-Pliocene (N17-N20) } \\
\text { Early Pliocene(N18-N19) } \\
\text { Pliosen (N16-N19). } \\
\text { Early Pliocene (N18-N19). }\end{array}$ & $\begin{array}{l}\text { Bulimina acuelata } \\
\text { Brizalina } \\
\text { Pullenia subcarinata } \\
\text { Uvigerina peregrine. } \\
\text { Bolivina quadrilateral } \\
\text { Globobulimina } \\
\text { Globocassidulina } \\
\end{array}$ & $\begin{array}{c}\text { open marine environment on } \\
\text { upper bathyal }\end{array}$ \\
\hline $\begin{array}{l}\text { Globorotalia tosaensis } \\
\text { Globigerinoides fistulosus } \\
\text { Globigerina venezuelana } \\
\text { Neoglobouadrina humerosa } \\
\text { Calcarina (benthic) }\end{array}$ & $\begin{array}{c}\text { Late Pliocene(N21) } \\
\text { Late Miocene-Early Pliocene (N16-N19 }\end{array}$ & & \\
\hline
\end{tabular}

\section{Pacalan Limestone Member (Menuran Formation)}

Pacalan Limestone Member consists of bioclastic limestone, crystalline and sandy limestones. This formation has limited distribution, namely the type location in the Village Pacalan, Klabang region, and around the Situbondo area, showing gradual boundary towards the Menuran Formation. The contact between the Menuran Formation and the Pacalan Member appears to be gradual. The limestones are typically bedded, in some places rather poorly bedded (Figure 7), containing predominantly fragments of planktonic foraminifera, coral fragments and other bioclasts. Towards the upper section, the limestones appear to be more chalky especially around Situbondo. The total thickness of this unit is estimated to be at least 800 metres.

These bioclastic limestones are mostly packstone and wackestone with abundant planktonic foraminifera (20-70\%) fragment, quartz, plagioclase, hornblende and biotite floating on the micritic matrix bounded by calcite spar cement. Visible porosity ranges between 2$10 \%$ showing predominantly micro vug from dissoluted matrix, cement or bioclast and inter-grain shell.

Micropaleontology analysis results showed the presence of abundant plankton foraminifera indicating Early Pliocene age (Table 2).

The co-occurrence of Globigerina venezuelana and Sphaeroidinella dehiscens indicates Early Pliocene age (N19). Some other faunas (Brizalina, Ammonia, Globocassidulina) suggest a mixing neritic (large forams) and batyal that characterizes a turbidite environment. 


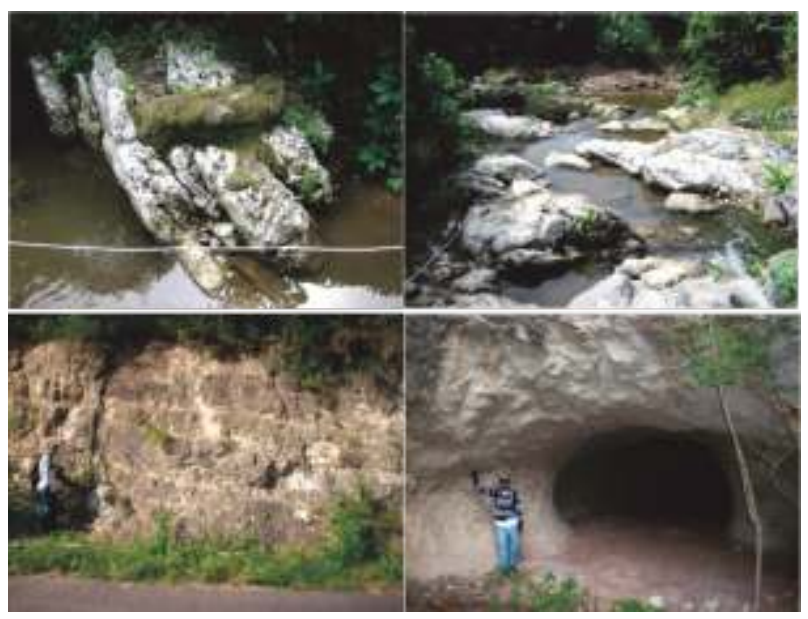

Figure 7. Bedded bioclastic limestone on stratigraphy Section Pacalan (KP), Klabang area ayered bioclastic limestone on the bottom (bottom left) and massive limestone and chalky (bottom right) are on track stratigraphy ST-2. Situbondo.

Table 2 Micropaleontology reports from the Pacalan Member suggest that the sequence was deposited in the Early Pliocene (N18-N20)

\begin{tabular}{|c|c|c|c|}
\hline Speriest & Intepreted ages & Spences & $\begin{array}{l}\text { interpreted Deposibons: } \\
\text { fintmenast }\end{array}$ \\
\hline 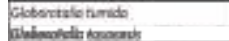 & \multirow{6}{*}{ 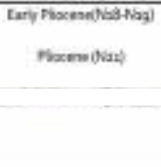 } & \multirow{6}{*}{ 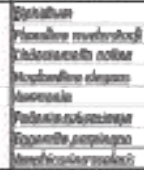 } & \multirow{6}{*}{ wopertanter } \\
\hline 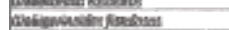 & & & \\
\hline cratived & & & \\
\hline 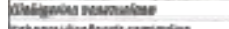 & & & \\
\hline 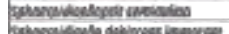 & & & \\
\hline 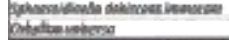 & & & \\
\hline
\end{tabular}

\section{Leprak Formation}

Leprak Formation Formation lies conformably above the Menuran Formation. The boundary of these two units in the Pacalan and Klabang area where the change from bioclastic limestone to calcareous sandstones can be clearly observed. In the Mlandingan area, the contact is marked by rare amount of rock and molluscs fragment at the contact between marl and calcareous sandstones.

Lithology variation of the Leprak Formation consists of alternating calcareous sandstones and tuffaceous sandstone, coarse sandstones with volcanic rock and molluscs shell fragments, breccias with basaltic and andesitic component (Figure 8) as well as fragments of shale and limestone (Figure 9) .

Sedimentary structures are well developed in sandstones and breccias in the form of graded bedding, parallel bedding planes and current ripple, which characterizes turbidite deposition.

The sandstone is generally feldspathic litharenite and 'wacke' with the main components of rock fragments (lithic) volcanic / pyroclastic, fine sandstone and limestone. Fragments are generally poorly sorted, coarse grain, even up to $1.5 \mathrm{~cm}$. Visual porosity ranges from $2-5 \%$, in the form of calcite dissolution and fine fractures. The tuffaceous sandstones consist mainly of vitric tuff with plagioclase, pyroxene, hornblende and biotite, as well as volcanic rock fragments/pyroclastic, bioclast of mainly plankton forams of and mollusc shells floating in a volcanic glass matrix. Porosity can be observed form of the cavity between the granules, dissolving matrix / cement and smooth fracture, ranging between 2 and $5 \%$.

The limestone sequence is primarily bioclastic and contain lithic volcanic material. The breccia predominantly composed of basaltic lava and pyroclastic materials with a small amount of shell (molluscs) floating on calcareous matrix (micritic and spary calcite of $15 \%$ ).

The benthic foraminifera, larger foraminifera and the presence of deep-sea plankton taxa forams generally indicate an open marine environment in upper batyal and several species indicate middle neritic environment The Leprak Formation was deposited in the Early Pliocene (N-19-N20) in an open marine environment in the upper bathyal with turbidite mechanism influence by volcanism.

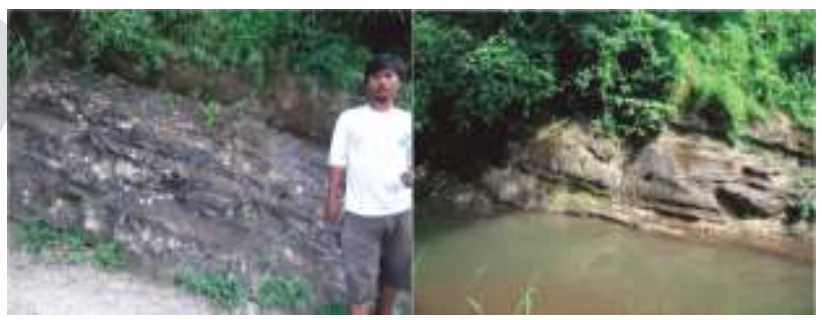

Figure 8. Outcrops of calcareous sandstones, well bedded either with the intercalation of breccia at the top (upper left). Location AP section, Mladingan area.

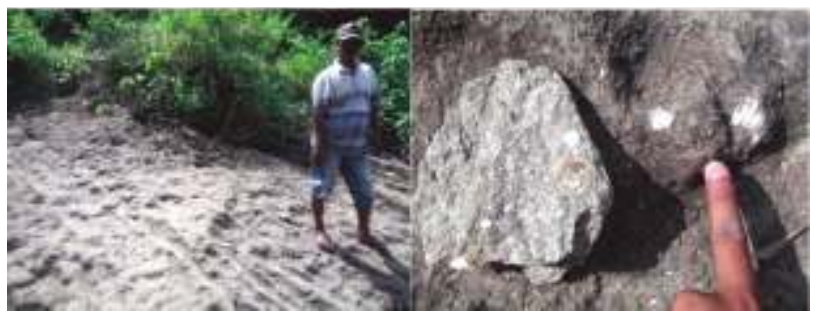

Figure 9. Breccia Sandstone Outcrops show current ripple structures (ripple marks, left) and the abundance of fragments of mollusc fossils (right). Location Section DAP, Alas Pinang Village, Mlandingan. 
Table 3 Micropaleontological analyses results from the Leprak Formation

\begin{tabular}{|c|c|c|c|}
\hline Species & Interpreted ages & Species & \begin{tabular}{|c|} 
Interpreted Depositional \\
Environment
\end{tabular} \\
\hline 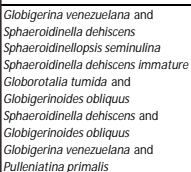 & $\begin{array}{l}\text { Early Pliocene (N19). } \\
\text { Early Pliocene (N19)-N20) } \\
\text { Early Pliocene (N19). } \\
\text { Early- Late Pliocene (N18-N22). } \\
\text { Early Pliocene (N19-N20). } \\
\text { Early Pliocene (N19-N20). }\end{array}$ & \multirow{2}{*}{ 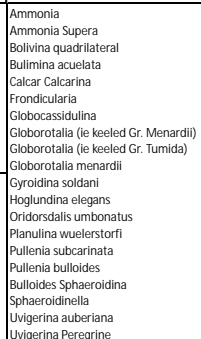 } & \multirow{2}{*}{ Upper bathyal } \\
\hline & & & \\
\hline
\end{tabular}

\section{Ringgit Formation}

The Ringgit Formation is predominated by volcanic products in form of lava, volcanic breccia, tuff and tuffaceous sandstone (Pendowo, 1991). This writer, in a regional geological map also concluded the presence of andesitic basalt and lava leusit (pyroxene and hornblende) which is part of the volcanic complex of Mount Ringgit. Excellent outcrop of volcanic breccias and tuffaceous sandstones with intercalations of limestone at the top can be observed along Kali Sampeyan, Situbondo area.

The volcanic breccia sequence is often found dark grey in color, containing fragments of basaltic and andesitic rocks in size from pebbles to boulders in coarse tuffaceous sandstone matrix. Bedding can be seen clearly in the rough-smooth boundary fragment (Figure 10 ), or on alternating sandstones. The total thickness of volcanic breccia layers reaches $50 \mathrm{~m}$.

Relatively thick layers of limestones capped the volcanic breccia. The base is a reefal limestone containing corals and algae, which changed gradually upwards into bioclastic limestones. At the top, it develops into an alternating of bioclastic limestone and sandstone with bedding planes increasingly thinning to upper part (Figure 11) where it predominantly massive tuffaceous coarse sandstone (Figure 12), with a thickness of more than $2 \mathrm{~m}$ and lesser carbonate rocks intercalations. Beds are thin complemented by parallel bedding and cross laminations structures. The total thickness of this formation is estimated to reach 500 metres (Pendowo, 1991).

Age determination of micro fossils yields insufficient information. Van Bemmelen (1949) concluded PlioPleistocene age for 'Ringgit Series' whereas from rock $\mathrm{K}$-Ar analysis alkali potassic and ultra-potassic, SoeriaAtmadja et al., (1994) concluded that the age of $2 \mathrm{Ma}$ or Late Pliocene.

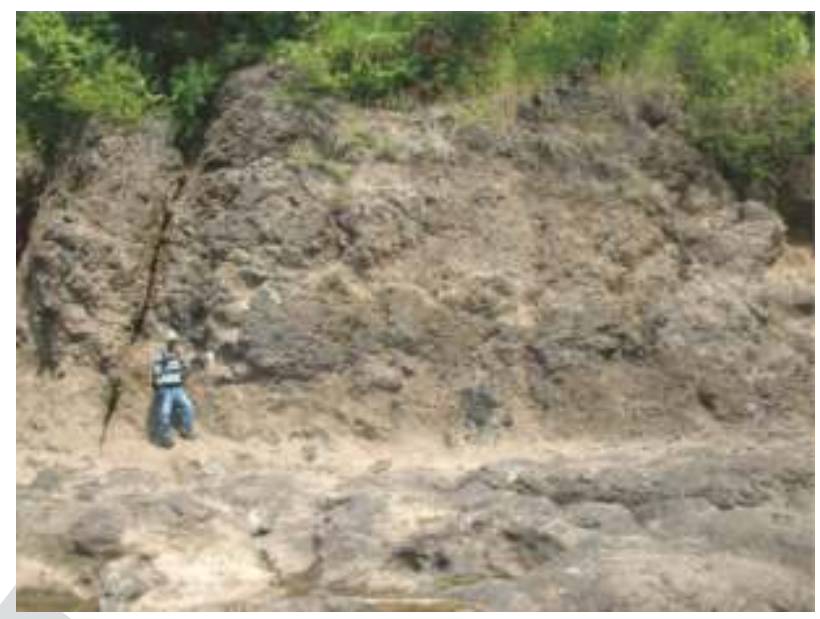

Figure 10. Volcanic breccia with basaltic igneous component. Section ST-1, K. Sampeyan, Situbondo. Individual alternating sandstones may reach thickness up to 2 metres.

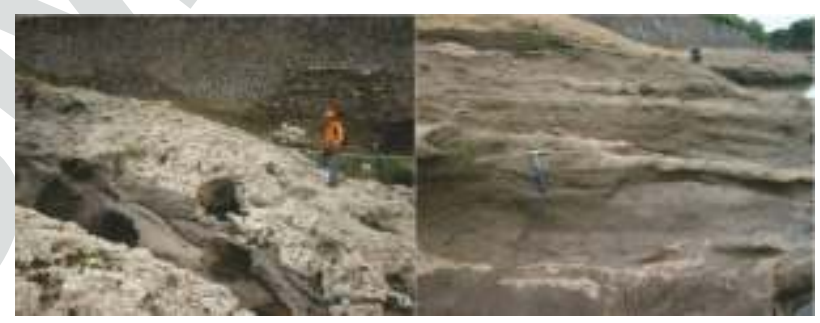

Figure 11. Reef limestone intercalation (left) and alternating limestone and sandstone (right) in section location-1 ST.

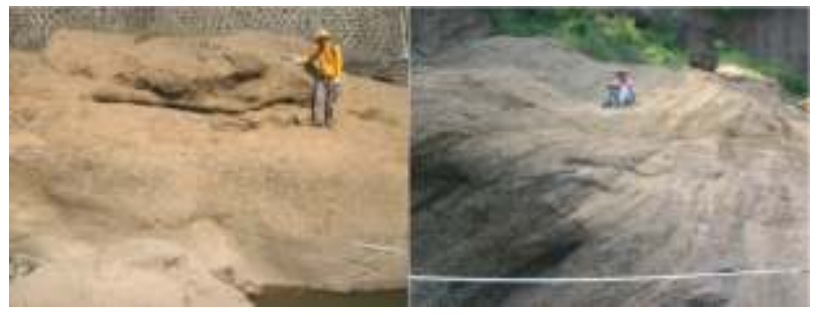

Figure 12. massif sandstones (left) and sandstone beds with sedimentary structures (right) on Section stratigraphy ST-1.

\section{Bagor Formation}

The Bagor Formation consists of pyroclastic rocks, characterized by alternating sandstone and tuffaceous breccia, and intercalations of polymict conglomerate in sandstones. The breccias generally have dacitic pumice component with a thickness of up to $3 \mathrm{~m}$. The tuffaceous sandstone is typically very coarse-grained, composed mainly of volcanic rock fragments. These rocks are generally less compact and friable. Many diagnostic layer is calcareous sandstone, showing sedimentary structures of graded bedding and parallel bedding (Figure 13). 


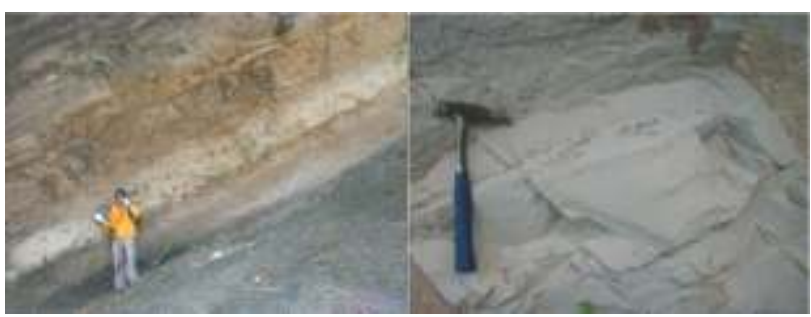

Figure 13. Tuffaceous sandstone bedding with a of conglomerate layer at the base (left) and tuff layers in sandstone (right) on Section-1 ST

Lithic sandstones in general with the main components of rock fragments (lithic) and bioclasts, disaggregated bad, consisting of mafic minerals, few hornblende and pyroxene and plagioclase with calcite cement. Limestone fragments and bioclast present locally. Porosity $(\sim 2 \%)$ seen as a result of dissolution and fine fractures.

This formation is interpreted to be unconformably deposited on the top of Ringgit Formation as indicated by different bedding attitude to the underlying Ringgit Formation which in some places shows significant slope $( \pm 250)$.

\section{Alluvium}

This unit is mainly distributed in the northern area showing cobbles, gravel, sands and fine-grained deposits in river and beach environment.

\section{STRUCTURAL GEOLOGY}

The study area is a part of a large east-west trending circular anticlinorium formed by Cenozoic, Late Miocene to Pliocene, rocks connecting Besuki and Situbondo to the south of Quarternary volcano, Gunung Ringgit-beser. Beds are dipping between 200-500 striking mainly NE-SW and E-W direction. Strike distribution and dip for the entire study area is shown in Figure 14. Some areas, like Mlandingan, show uneven strike distribution due to the outcrop limitation.

Reverse fault structures are commonly found around Situbondo area (Figure 15). Reverse fault crosscuts alternating sandstone and breccia of the Ringgit Formation, with a slope towards the SW ends following the slope of the layer as a 'bedding-plane fault'. NE-SW trending fractures occurred within the core of the anticline.

More intensive structures exposed around Klabang where steep fold limbs, up to 700, belong to the anticlines trending NE-SW plunged towards the NE.
Parts of the limbs are unconformably overlain by the Bagor Formation. N-S and WNW-ESE trending strike slips are also common showing predominantly dextral sense of movement (Figure 16). Normal fault evidence commonly encountered as a fault scarp, especially shown lineament direction. Fault scarp in the south of Menuran Mt. showing normal fault bounding Menuran Formation and the younger Ringgit Formation.

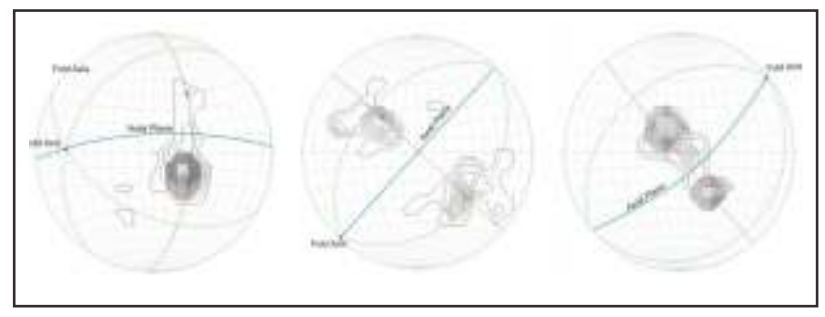

Figure 14. Distribution of strike and dip of the bedding in the area (from left to right) Mlandingan, Klabang and Situbondo.

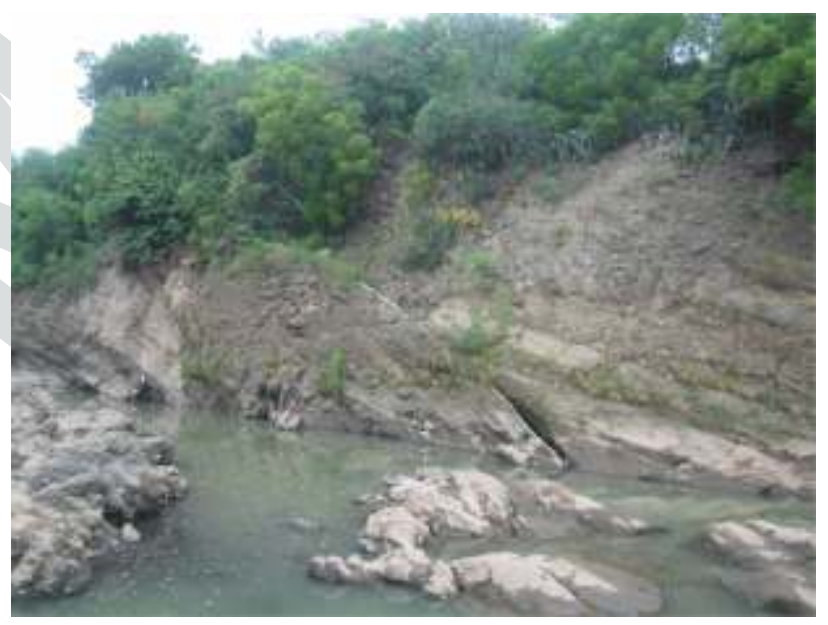

Figure 15. Reverse Fault with dip $25^{\circ}$ towards the SW on the Ringgit Formation. Location along Sampeyan River, Situbondo.

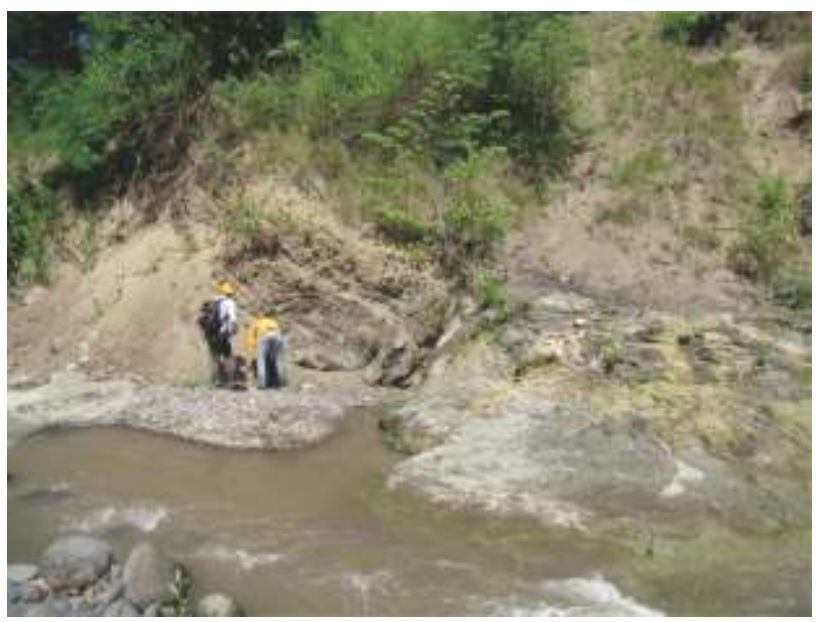

Figure 16. Strike slip fault in the Leprak Formation with NW-SE direction. Location Bluncong River (KB-3), Klabang Area. 
In Mlandingan area faults are scarcely exposed due to the poor exposure. In the west mapping area of Mlandingan bedding attitude relatively NS trending indicates the changes which do not compliance with the anticline direction relatively NW-SE. Comparable to the fold trends prominent in Rembang region interpreted to be en-echelon fold system (Husein et al., 2015). The existence of NS Scarp which is the limit contact between the Ringgit and Leprak Formations is interpreted as the NS trending normal fault.

The overall structural configuration in the area Situbondo, Klabang and Mlandingan shown the general structure of a curved crease following major volcanic centers of the Mount Ringgit-Beser. Fold structures, as known in Java, related to major tectonic happened to Plio-Pleistocene. Circular shapes are interpreted as a result of the later volcanism and magmatism activities (Late Pleistocene; van Bemmelen, 1949).

\section{GEOLOGICAL SYNTHESIS}

From the stratigraphic succession in the area of Situbondo, the basin filling phase began in Late Miocene time represented by the Menuran Formation and Pacalan Member. The Menuran Formation is a distal turbidite deposit on the upper bathyal environment influenced by strong volcanic activity. The Pacalan limestone in the area Klabang, Bondowoso, which position relative to the south west, generally contains more abundant and coarse grained bioclasts. Sedimentation of this formation is interpreted as a mixing environment proximal to distal turbidite, from both volcanics and carbonate sources. Considering the Late Miocene sediments distribution in the north Situbondo (EML-LAPI ITB internal report, 2010), it is concluded that the development of sedimentation is to the north, towards the deeper siliciclastic-carbonates facies. In the Early Pliocene, sedimentary sequences in the western part (Mlandingan) shows the nature of proximal turbidite volcaniclastic (Leprak Formation) relatively shallower (with the presence of shallow clastic material that more abundant) compared to the eastern part. This suggests that the basin is deeper towards the east. During the Late Pliocene, the region of Situbondo was dominated by development of volcanoclastic proximal turbidite sedimentation of the Leprak Formation, along with volcanic activity in the south while the Globigerinid marl of Paciran Formation was deposited (EML-LAPI ITB internal report, 2010) in the northern side of the basin making the offshore region of Situbondo more likely to deposit deeper turbidite facies (distal).
Plio-Pleistocene deformation in Java is generally believed to be the last major tectonic period, which forms the west-east trending structures (Java Structural Patterns). In Situbondo area, folding structures in this direction involves the Tertiary rocks of Menuran Formation, Pacalan Member and Leprak Formation. Volcanic activity persists, and possibly increased, particularly in the Situbondo area, with the existence of volcanic activity of Ringgit-Beser in Pleistocene $(<2$ Ma, Soeria-Atmadja et al., 1994).

The volcanic activity of Ringgit Mtn. started as submarine volcanoes of or at least near the sea, in line with the nature of breccia sedimentation of the Ringgit Formation showing bedding structures, graded bedding (not well developed), with floating fragments in the matrix, which characterizes the mud flow sediments. The presence of reef limestones in the middle supports this conclusion. It is concluded that early deposition of the Ringgit Formation was occurred in the marine environment, on slopes that were likely close to the volcanic body. Limestone reefs that grow above the volcanic breccia is only limited (maximum thickness of $5 \mathrm{~m}$ ), which were then reworked and deposited as bioclastic limestone in the younger sequence. It is possible that limestone growth stalled by increasing volcanic activities, whilist was uplifted and became shallow marine conditions. This was supported by deposition environmental changes on the upper sequence Ringgit Formation became a fluvial system (braided stream?). The Ringgit-Beser volcanic activity has also led to the relative uplift causing the fold structural configuration of existing Tertiary folded rocks into a circular shape in the proximity of volcanic core (in the middle of Situbondo anticlinorium). The entire area is generally covered by younger volcanic deposits (Bagor Formation) widely spread across from the north to the south coast (Astutik, 2015).

Anticline structures toward offshore have been interpreted consistently as part of the anticline limb towards the north. Based on well data (e.g. Baluran-1, Madura Q-1; EML-LAPI ITB internal report (2010)) and subsurface interpretation, the Menuran Formation is interpreted to be the time equivalent of Paciran Formation in the north and the overlying the Leprak Formation subsequently interpreted to be comparable to the Pamekasan Formation (in Madura Island). However the lithological association is rather different; The Leprak Formation is volcanoclastic deep-sea sediment, whereas the Pamekasan Formation represents a shallow marine carbonate facies. 


\section{REVIEW OF PETROLEUM SYSTEMS}

There has not been any record of the presence of petroleum, both on land and offshore. Sedimentary rocks in the Situbondo area are in the late stage of Tertiary period ranging from Late Miocene to Pliocene (N18 - N22). However, slightly further to the west there appear to be a working petroleum system utilizing young volcaniclastic sandstone of Pleistocene sequence in Wunut Field (Kusumastuti, 1999).

Rock formations with potential possibilities as a source rock is the formation containing high organic content, including marl unit with abundant forams from the Menuran Formation and Pacalan Limestone (Satyana \& Purwaningsih, 2003). However, the possibility of maturity is very small for these formations. Future geochemical data from these rocks may change the interpretation.

Potential reservoir rocks in Besuki and Situbondo areas are possibly from the Menuran Formation, particularly in globigerinid sandstone, limestone of Pacalan and sandstone of the Leprak Formation. The first two formations is possible potential as a reservoir with porosity greater than $10 \%$. This formation can be correlated with the Paciran Formation in the offshore area (Baluran-1). The Leprak Formation in general is deep-sea sediment with dominant volcanoclastic components, and has undergone intensive recrystallization. The observed porosity is generally reached a maximum of 5\%. The lithologic nature which support for the seals is not found in onshore area of Situbondo. The formation covering Tertiary rocks is the volcanoclastic deposit of Ringgit Formation; one of the oldest equivalent product of a widespread older volcanic activity forming a well-known complex namely the AWVC (Arjuno Welirang Volcanic Complex) with high heat flow anomaly (Harijoko et al., 2018). Towards the north in the offshore area, the rock units that can be compared at this age is the Pamekasan Formation which form a fairly thick, massive marl.

Anticline structural trap with the direction of EW and NE-SW was interpreted as to be formed in PlioPleistocene time. Volcano-tectonic activities in the Pleistocene time have resulted in the uplifted and folded Tertiary rock units and actually have been exposed on the surface which in return may compromise the trapped hydrocarbons.

\section{CONCLUSIONS}

Development of sedimentation began in Late Miocene time, when the Menuran Formation was deposited, following by the Pacalan limestones deposition in the proximal to distal part with principal carbonate sources from the litoral facies from the south. The development of sedimentation is interpreted to develop a deeper silisiclastic and carbonates facies towards the north. In the Early Pliocene, sedimentary sequences in western part shows predominantly volcanoclastic proximal turbidite of the Leprak Formation. This indicates that shallower lead became the deeper facies to the east. Up to Late Pliocene, the region was dominated by developments proximal turbidite sedimentation of volcanoclastic of the Leprak Formation, along with volcanic activity in the south.

Deformation of Plio-Pleistocene in Java was generally believed to be the last major tectonic period, which formed the west-east trending structures. Volcanic activity persists, and increases, with the activity of the Ringgit-Beser volcano in Pleistocene times. This late events, magmatism, volcanism and uplift have contributed to the last structural configuration of the area.

The petroleum system on the onshore regions around Besuki and Situbondo areas appear to be incomplete due to lacking information in the source rock intervals as well as trap integrity due to young deformation. Future works are still needed to determine the source rock interval quality and maturity as well as to postulate the critical timing whether if there was any hydrocarbon generated and migrated in post Plio-Pleistocene deformation.

\section{ACKNOWLEDGEMENTS}

The study area was part of the PT Energi Mineral Langgeng (EML) Southeast Madura Block that has been relinquished in 2012. We thank the management of PT EML, particularly Mr. Sopandi Tossin and Mr. Sukma Ubaidillah, for supporting of the field work, laboratory analysis and permission for published of the part of the data that has been executed in 2010 . 


\section{REFERENCES}

Agustyanto, DA. dan Santosa, S., 1993, Geologi Lembar Situbondo, Jawa Timur, Pusat Penelitian dan Pengembangan Geologi.

Astutik, L. T., 2015. Pemetaan Pola Sebaran Gumuk Menggunakan Metode Sistem Informasi Geografis di Kabupaten Jember. Skripsi di Program Studi Fisika, FMIPA, Universitas Jember.

EML Southeast Madura Block-LAPI ITB (internal report), 2010, Geological and Geophysical Study of Southeast Madura Block, East Java, Internal Report.

Hall, R. (2012) Late Jurassic Cenozoic reconstruction of the Indonesian region and the Indian Ocean. Tectonophysics, 570-571, pp. 1-41.

Harijoko, A., Utama, H. W., Husein, S. 2017. Volcanism and Structural Geology on Geothermal Area of the Arjuno Welirang Volcanic Complex, East Java. Proceedings The 5 Indonesia International Geothermal Convention \& Exhibition (IIGCE) 2017; 2 - 4 August 2017, Cendrawasih Hall - Jakarta Convention Center, Indonesia

Husein, S., K. Kakda, dan H.F.N. Aditya. 2015. Mekanisme Perlipatan En-Echelon di Antiklinorium Rembang Utara, Prosiding Seminar Nasional Kebumian ke-8 Jurusan Teknik Geologi Fakultas Teknik Universitas Gadjah Mada, Yogyakarta, GEO41, pp 224-234

Kusumastuti, A., Darmoyo Agung B., Suwarlan, W., Sosromihardjo, S.P.C., 1999, The Wunut Field : Pleistocene Volcaniclastic Gas Sand in East Java. Proceeding Indonesia Petroleum Association, Twenty-Seventh Annual Convention \& Exhibition.

Marks, P., 1957, Stratigraphic Lexicon Of Indonesia, Pusat Djawatan Geologi Bandung, Publikasi Keilmuan No. 31, Seri Geologi.

Mudjiono, Rachmat, and Pireno, Gadjah Eko, 2001, Exploration of The North Madura Plaform Offshore East Java Indonesia, Proceedings, IPA, 28th Annual Convention \& Exhibition.

Mulhadiono, Harsono, P., Asikin, S., 1984, Tinjauan Stratigrafi dan Tataan Tektonik di Pulau Madura, Jawa Timur, Pusat Penelitian dan Pengembangan Geologi, Bandung.

Pendowo, B., 1991, Geologi Lembar Besuki, Jawa Timur, Pusat Penelitian dan Pengembangan Geologi.

Sapiie, B., Harsolumakso, A.H., Prasetyadi, C., Asikin, S., 2006. Paleogene Tectonic Evolution and Sedimentation of East Java Basin (extended abstract), Persidangan Bersama Geosains UKM-ITB, 20-26 Disember 2006.

Satyana A. H., Purwaningsih M.E.M., 2003, Geochemistry of the East java Basin: New Observations on Oil Grouping, Genetic Gas Types and Trends of Hydrocarbon Habitats, Proceedings, IPA, 29th Annual Convention \& Exhibition.

Smyth, H., Hall, R., Nichols G. 2008, Cenozoic volcanic arc history of East Java, Indonesia: The stratigraphic record of eruptions on an active continental margin, in Draut, A.E., Clift, P.D., and Scholl, D.W., eds., Formation and Applications of the Sedimentary Record in Arc Collision Zones: Geological Society of America Special Paper 436, p. 199-222, doi: 10.1130/2008.2436(10)

Soeria-Atmadja R., Maury, R. C., Bellon, H., Pringgoprawiro, H., Polve M., and Priadi B. 1994. Tertiary magmatic belts in Java. Journal of Southeast Asian Earth Sciences, Volume 9, Issues 1-2, January-February 1994, Pages $13-27$

Sribudiyani., Muchsin. N., Ryacudu. Rudy., Kunto. T., Astono. P., Prasetya. I., Sapiie. B., Asikin. S., Harsolumakso. A.H., Yulianto. I., 2003, The Collision of the East Java Microplate and Its Implication for Hydrocarbon Occurrences in The East Java Basin. Proceeding Indonesia Petroleum Association, Twenty-Ninth Annual Convention \& Exhibition.

van Bemmelen, R. W., 1938, The Ringgit Beser. A Folded Alkali-Volcano in East Java, Natuurkundig Tijdschrift voor Nederlandsch Oost Indie, Deel XCVIII.

van Bemmelen, R. W., 1949, The Geology of Indonesia, Martinus Nijnhoff, The Hague, Netherlands, Vol. I A, p. 546590. 